Journal of Nutrition College, Volume 3, Nomor 1, Tahun 2014, Halaman 90 - 97

Online di : http://ejournal-s1.undip.ac.id/index.php/jnc

\title{
PERBEDAAN PERUBAHAN KADAR KOLESTEROL LDL SETELAH PEMBERIAN EKSTRAK DAN REBUSAN DAUN SALAM (EUGENIA POLYANTHA) PADA TIKUS SPRAGUE DAWLEY YANG DIBERI PAKAN TINGGI LEMAK
}

\author{
Astri Praba Shinta, Martha Irene Kartasurya ${ }^{*}$ \\ Program Studi Ilmu Gizi Fakultas Kedokteran Universitas Diponegoro \\ J1.Dr.Sutomo No.18, Semarang, Telp (024) 8453708, Email : gizifk@ undip.ac.id
}

\begin{abstract}
Background : Dyslipidemia is a lipid metabolism disorder which is signed by the increased levels of total cholesterol, Low Density Lipoprotein (LDL) cholesterol, triglycerides, and decreased levels of High Density Lipoprotein (HDL). Quercetin contained in a bay leafflavonoid is known to reduce LDL cholesterol levels.

Method : This study was conducted in laboratory experiments with pre-post test randomized control group design. Subject were 24 male Sprague Dawley rats aged 8 weeks old who were divided into 4 groups, each group consisted of 6 rats. The 4 groups received standard feed plus high fat diet for 19 days. The first group is a positive control group and the second group received $0.18 \mathrm{~g} / \mathrm{kg} \mathrm{BW}$ simvastatin. The third group received $0.034 \mathrm{~g} / \mathrm{kg} \mathrm{BW}$ extract of bay leaves, and the fourth group received $0.72 \mathrm{~g} / \mathrm{kg} \mathrm{BW}$ infused water of bay leaves. LDL cholesterol levels were determined by CHOD-PAP method. Normality of data distribution was tested with Shapiro-Wilks. Data was analyzed with paired t-test, Kruskall Wallis, and One Way Anova.

Result : The results showed an increased of LDL cholesterol levels, $79.9 \mathrm{mg} / \mathrm{dL}$ in positive control group; 38.3 $\mathrm{mg} / \mathrm{dL}$ in infused water group; $26.2 \mathrm{mg} / \mathrm{dL}$ in extract group; and $2.9 \mathrm{mg} / \mathrm{dL}$ in simvastatin group. Positive control group had the highest LDL cholesterol levels compared to the other groups. The increase of LDL cholesterol levels in extract group $(26.2 \mathrm{mg} / \mathrm{dL})$ was lower than the infused water group $(38.3 \mathrm{mg} / \mathrm{dL})$. Post Hoc tests showed significant difference in LDL cholesterol levels between simvastatin and positive control; simvastatin and extract; simvastatin and infused water; extract and positive control; extract and infused water; and infused water and positive control groups.

Conclusion : Bay leaf infused water feeding could not decrease LDL cholesterol levels on Sprague Dawley rats on high fat diet but increased LDL cholesterol levels lower than the positive control group and increased higher than the extract and simvastatin group.

Keywords : bay leaf; LDL cholesterol; Sprague Dawley rats
\end{abstract}

\begin{abstract}
ABSTRAK
LatarBelakang : Dislipidemia merupakan gangguan metabolisme lipid berupa peningkatan kadar kolesterol total, kolesterol Low Density Lipoprotein (LDL), trigliserida, dan penurunan kolesterol High Density Lipoprotein (HDL). Quercetin yang terkandung dalam flavonoid daun salam dapat menurunkan kadar kolesterol LDL.

Metode : Jenis penelitian ini adalah eksperimental laboratorik dengan pre-post test randomized control group design. Subjek penelitian adalah 24 tikus Sprague Dawley jantan berumur 8 minggu yang dibagi menjadi 4 kelompok, yang terdiri dari 6 ekor tikus. Keempat kelompok diberi pakan standar dan diet tinggi lemak. Kelompok pertama merupakan kelompok kontrol positif dan kelompok kedua diberi 0,18 g/kg BB simvastatin. Kelompok ketiga diberi $0,034 \mathrm{~g} / \mathrm{kg} \mathrm{BB}$ ekstrak daun salam dan kelompok keempat diberi 0,72 $\mathrm{g} / \mathrm{kg}$ BB rebusan daun salam. Kadar kolesterol LDL ditentukan dengan metode CHOD-PAP. Normalitas distribusi data diuji dengan Shapiro-Wilks. Data dianalisis dengan uji paired t-test, Kruskall Wallis, dan One Way Anova.

Hasil : Hasil penelitian menunjukkan adanya peningkatan kadar kolesterol LDL yaitu 79,7 mg/dL pada kelompok kontrol positif; 38,3 mg/dL pada kelompok rebusan; 26,2 mg/dL pada kelompok ekstrak; serta 2,9 mg/dL pada kelompok simvastatin. Kelompok kontrol positif mengalami peningkatan kadar kolesterol LDL paling tinggi dibandingkan dengan kelompok lainnya. Peningkatan kadar kolesterol LDL pada kelompok ekstrak (26,2 mg/dL) lebih rendah dibandingkan dengan kelompok rebusan $(38,3 \mathrm{mg} / \mathrm{dL})$. Hasil uji Post Hoc menunjukkan bahwa terdapat perbedaan perubahan kadar kolesterol LDL antara kelompok simvastatin dan kontrol positif; simvastatin dan ekstrak; simvastatin dan rebusan; ekstrak dan kontrol positif; ekstrak dan rebusan; serta rebusan dan kontrol positif.

Simpulan : Pemberian rebusan daun salam tidak dapat menurunkan kadar kolesterol LDL pada tikus Sprague Dawley yang diberi pakan tinggi lemak namun peningkatan kadar kolesterol LDL pada kelompok rebusan lebih rendah dibandingkan dengan kelompok kontrol positif serta lebih tinggi peningkatannya dibandingkan dengan kelompok ekstrak dan simvastatin.
\end{abstract}

Kata kunci : daun salam; kolesterol LDL; tikus Sprague Dawley

\footnotetext{
${ }^{*}$ Penulis Penanggungjawab
} 


\section{PENDAHULUAN}

Dislipidemia merupakan gangguan metabolisme lipid berupa peningkatan kadar kolesterol total, kolesterol Low Density Lipoprotein (LDL), trigliserida darah, dan penurunan kolesterol High Density Lipoprotein (HDL). Faktor penyebab dislipidemia di Indonesia yaitu perilaku masyarakat yang cenderung mengkonsumsi makanan rendah serat dan tinggi lemak. ${ }^{1}$ Berdasarkan data World Health Organization (WHO) pada tahun 2011, sebesar $35,1 \%$ penduduk Indonesia mengalami peningkatan kadar kolesterol darah. ${ }^{2}$ Penelitian yang dilakukan pada empat kota besar di Indonesia (Jakarta, Bandung, Yogyakarta, dan Padang) tahun 2004 menunjukkan keadaan dislipidemia berat pada masyarakat yang berusia 55 tahun dengan jumlah $56 \%$ di kota Padang dan Jakarta, 52,2 \% di Bandung, dan 27,7 \% di Yogyakarta. Penelitian ini juga mengemukakan bahwa prevalensi dislipidemia lebih banyak terjadi pada wanita dibandingkan pria. ${ }^{3}$ Selain itu, penelitian di kota Ternate menggambarkan prevalensi dislipidemia mencapai 59,2\% pada tahun $2008 .{ }^{4}$

Seseorang yang mengalami dislipidemia memiliki risiko lebih tinggi terkena penyakit kardiovaskuler terutama penyakit jantung. ${ }^{5}$ Pola makan yang tinggi kolesterol dan asam lemak jenuh disertai frekuensi makan yang tinggi menyebabkan kadar kolesterol sulit dikontrol. ${ }^{6}$ Penyakit jantung merupakan salah satu penyakit yang mematikan di dunia, jumlah penderita penyakit ini terus bertambah setiap tahunnya. Data dari World Health Organization (WHO) tahun 2008 menunjukkan bahwa 17,3 juta kematian di dunia disebabkan oleh penyakit kardiovaskuler dengan 7,3 juta diantaranya disebabkan oleh penyakit jantung koroner. ${ }^{7}$

Faktor risiko penyakit jantung koroner antara lain faktor risiko yang tidak dapat dimodifikasi dan faktor risiko yang dapat dimodifikasi. Faktor risiko yang tidak dapat dimodifikasi, misalnya usia, jenis kelamin, dan riwayat penyakit keluarga. Sedangkan faktor risiko yang dapat dimodifikasi antara lain hipertensi, diabetes mellitus, kebiasaan merokok, obesitas, menopause, pola makan tidak sehat, dan dislipidemia. ${ }^{1}$

LDL merupakan lipoprotein berdensitas rendah yang berfungsi mengangkut lemak ke jaringan. Peningkatan LDL kolesterol dalam jangka waktu lama dapat menyebabkan terjadinya penimbunan lemak di dalam lapisan pembuluh darah atau plak kolesterol. Plak kolesterol mengakibatkan terjadinya pengerasan dan penyempitan pembuluh darah sehingga suplai darah ke otot jantung berkurang yang kemudian menyebabkan penyakit jantung. Peningkatan kolesterol antara lain disebabkan oleh genetik, usia, jenis kelamin, aktivitas fisik, penyakit penyerta, kebiasaan merokok, kebiasaan minum kopi, dan pengaturan pola makan. Pengaturan pola makan dengan mengurangi asupan makanan dan minuman yang mengandung lemak dapat membantu untuk mengontrol dislipidemia. ${ }^{8}$

Kontrol terhadap dislipidemia selain dengan pengaturan pola makan juga dapat dilakukan dengan pengobatan tradisional. Indonesia kaya akan tanaman yang dapat digunakan sebagai bahan baku alami untuk pengobatan. Indonesia yang beriklim tropis merupakan negara dengan keanekaragaman hayati terbesar kedua di dunia setelah Brazil. Indonesia memiliki sekitar 25.000-30.000 spesies tanaman yang merupakan $80 \%$ dari jenis tanaman di dunia dan $90 \%$ dari jenis tanaman di Asia. ${ }^{9}$

Salam merupakan tanaman yang dikenal masyarakat Indonesia sebagai bumbu karena memiliki aroma yang khas. Bagian daun dari tanaman salam memiliki rasa kelat dan bersifat astringent. Keberadaannya yang mudah ditemukan serta memiliki nilai ekonomis merupakan kelebihan dari daun salam. Masyarakat biasa mengkonsumsi ekstrak dan rebusan daun salam untuk mengobati kolesterol tinggi, diabetes mellitus, hipertensi, gastritis, dan diare. Rebusan daun salam lebih praktis dan lazim untuk dikonsumsi serta memiliki nilai yang ekonomis dibandingkan dengan konsumsi ekstrak daun salam, akan tetapi dari segi kualitas bahan-bahan aktif yang terkandung dalam ekstrak daun salam lebih tinggi dibandingkan dengan rebusan daun salam. Dewasa ini, masyarakat lebih memilih mengkonsumsi obat herbal dibandingkan dengan mengkonsumsi obat-obatan yang diproduksi pabrik seperti Simvastatin. Simvastatin merupakan obat yang dapat menurunkan kadar kolesterol LDL, trigliserida, dan kolesterol total serta dapat meningkatkan kadar kolesterol HDL. Simvastatin juga digunakan untuk menurunkan risiko stroke dan serangan jantung. ${ }^{10}$

Penelitian mengenai pengaruh pemberian ekstrak daun salam (Eugenia polyantha) terhadap kadar LDL kolesterol serum tikus jantan galur wistar hiperlipidemia menunjukkan bahwa dosis 0,72 g/hari dapat menurunkan kadar LDL kolesterol paling tinggi dibanding dengan kelompok lainnya $(0,18 \mathrm{~g} /$ hari dan $0,36 \mathrm{~g} / \mathrm{hari}) .{ }^{11}$ 
Secara khusus penelitian ini bertujuan untuk mengetahui perbedaan penurunan kadar kolesterol LDL setelah pemberian ekstrak dan rebusan daun salam (Eugenia polyantha) pada tikus Sprague Dawley yang diberi pakan tinggi lemak.

\section{METODE PENELITIAN}

Penelitian ini merupakan penelitian experimental laboratorik dengan jenis pre-post test randomized control group design yang dilakukan di Laboratorium Pusat Studi Pangan dan Gizi PAU UGM Yogyakarta selama 19 hari dengan proses aklimitasi 3 hari dan perlakuan 14 hari. Variabel bebas dalam penelitian ini adalah pemberian ekstrak dan rebusan daun salam (Eugenia polyantha) sedangkan variabel terikat dalam penelitian ini adalah kadar kolesterol LDL.

Sampel yang digunakan sebanyak 24 ekor tikus jantan Sprague Dawley dengan berat badan rata-rata 140-260 gram dan berumur 8 minggu yang diperoleh dari Lembaga Penelitian dan Pengujian Terpadu (LPPT) UGM Yogyakarta. Pada penelitian ini menggunakan 4 kelompok perlakuan yang masing-masing terdiri dari 6 ekor tikus. Penentuan besar sampel menggunakan rumus besar sampel eksperimental Federer, yaitu (t-1) (n-1) $\geq 15$. Pengelompokkan tersebut dilakukan secara acak sederhana dengan pemberian nomor pada ekor tikus yang kemudian nomor tersebut diambil dengan sistem lotere. Masing-masing kelompok terdiri dari 6 ekor tikus yang dirawat dalam kandang individu. Keempat kelompok diberi pakan standar AD II dan diet tinggi lemak. Kelompok pertama merupakan kelompok kontrol positif dan kelompok kedua diberi $0,18 \mathrm{~g} / \mathrm{kg}$ BB simvastatin. Kelompok ketiga diberi $0,034 \mathrm{~g} / \mathrm{kg}$ BB ekstrak daun salam dan kelompok keempat diberi $0,72 \mathrm{~g} / \mathrm{kg}$ BB rebusan daun salam yang diberikan secara sonde selama 17 hari. Diet tinggi lemak diambil dari lemak jenuh bagian perut daging babi yang diberikan secara sonde sebanyak $10 \%$ dari pakan standar.

Ekstrak daun salam yang diberikan dibuat dengan metode maserasi yang diawali dengan pencucian daun salam pada air mengalir, kemudian dikeringkan di dalam lemari pengering suhu $45^{\circ} \mathrm{C}$ selama 48 jam. Daun salam tersebut diserbuk menggunakan mesin penyerbuk dengan diameter lubang saringan $1 \mathrm{~mm}$ kemudian serbuk tersebut ditambah ethanol $70 \%$. Serbuk diaduk selama 30 menit, didiamkan 24 jam, kemudian disaring (diulang 3 kali). Cairan yang telah disaring (filtrate) diuapkan menggunakan Vacuum Rotary Evaporator pada suhu $60{ }^{\circ} \mathrm{C}$ dengan pemanas waterbath. Ekstrak yang mengental dituang dalam cawan porselin kemudian dipanaskan dengan waterbath suhu $70{ }^{\circ} \mathrm{C}$ sambil terus diaduk. Hasil ekstrak daun salam ditimbang dan dikemas, kemudian disimpan pada suhu $4{ }^{\circ} \mathrm{C}$. Proses perebusan daun salam untuk persiapan perlakuan kelompok rebusan daun salam dilakukan selama 30 menit dengan suhu $90^{\circ} \mathrm{C}$. Proses perebusan ini dilakukan 3 kali pada hari ke-5, ke-11, dan ke-18 . Air rebusan daun salam yang telah dibuat tersebut kemudian disimpan pada lemari pendingin untuk digunakan selama 7 hari kemudian melakukan perebusan kembali untuk digunakan pada 7 hari berikutnya. Ekstrak dan rebusan daun salam ini diberikan 1 kali dalam sehari secara sonde.

Pemeriksaan kadar kolesterol LDL dilakukan dengan metode cholesterol oxidase phenol aminophenazone (CHOD-PAP) yang diawali dengan pengambilan sampel darah sebanyak $2 \mathrm{ml}$ pada bagian sinus orbitalis. Kadar kolesterol LDL awal diperiksa sebelum dilakukan perlakuan, sedangkan kadar kolesterol LDL akhir diperiksa setelah dilakukan 14 hari perlakuan. Data-data yang telah diperoleh diolah dengan menggunakan program komputer dengan melakukan uji normalitas menggunakan uji Shapiro-Wilk kemudian data yang berdistribusi normal dilanjutkan dengan uji statistik parametrik Anova. Data yang tidak berdistribusi normal, dilanjutkan dengan uji statistik non parametrik Kruskal Walis. Perbedaan kadar kolesterol LDL sebelum dan sesudah perlakuan dilakukan dengan uji paired $t$-test. 


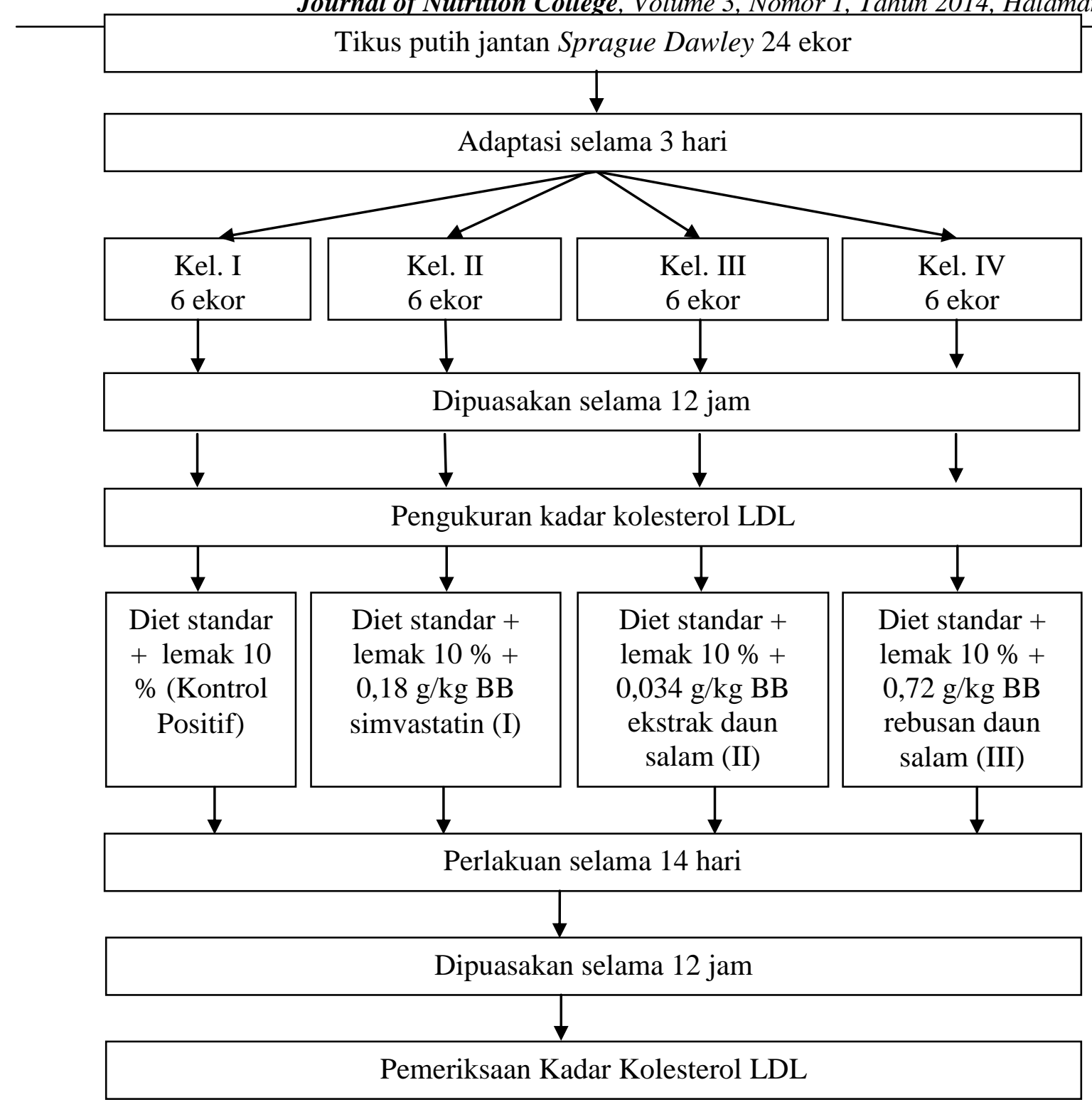

Gambar 1. Kerangka Kerja

\section{HASIL PENELITIAN}

\section{Karakteristik Sampel}

Daun salam segar yang dibuat dalam dua macam yaitu ekstrak dan rebusan daun salam diuji pada Laboratorium Pusat Studi Pangan dan Gizi PAU UGM Yogyakarta. Hasil yang diperoleh adalah kandungan flavonoid pada rebusan daun salam yaitu 24,50 ppm, sedangkan kadar flavonoid yang terkandung dalam ekstrak daun salam sebesar 11181,02 ppm. Hal ini menunjukkan bahwa kandungan flavonoid pada ekstrak daun salam lebih tinggi dibandingkan dengan kandungan flavonoid yang terkandung dalam rebusan daun salam.

Tabel 1. Perbedaan Kandungan Flavonoid pada Ekstrak dan Rebusan Daun Salam (Eugenia polyantha)

\begin{tabular}{clccc}
\hline \multirow{2}{*}{ No } & \multirow{2}{*}{ Jenis Sampel } & \multicolumn{3}{c}{ Kandungan Flavonoid (ppm) } \\
\cline { 3 - 5 } & & I & II & Rata-rata \\
\hline 1. & Rebusan & 24,83 & 24,16 & 24,50 \\
2. & Ekstrak & 11167,94 & 11194,09 & 11181,02 \\
\hline
\end{tabular}

Dua puluh empat tikus Sprague Dawley berjenis kelamin jantan berumur delapan minggu dengan berat badan rata-rata $140-260$ gram dipelihara dalam kandang individu. Tidak terdapat tikus yang mati pada masing-masing kelompok selama perlakuan berlangsung. Perubahan berat badan dan asupan pakan tikus dipantau setiap hari dengan penimbangan berat badan dan sisa pakan. 
Tabel 2. Perbedaan Berat Badan Tikus pada Hari Ke-1 sampai Hari ke-19

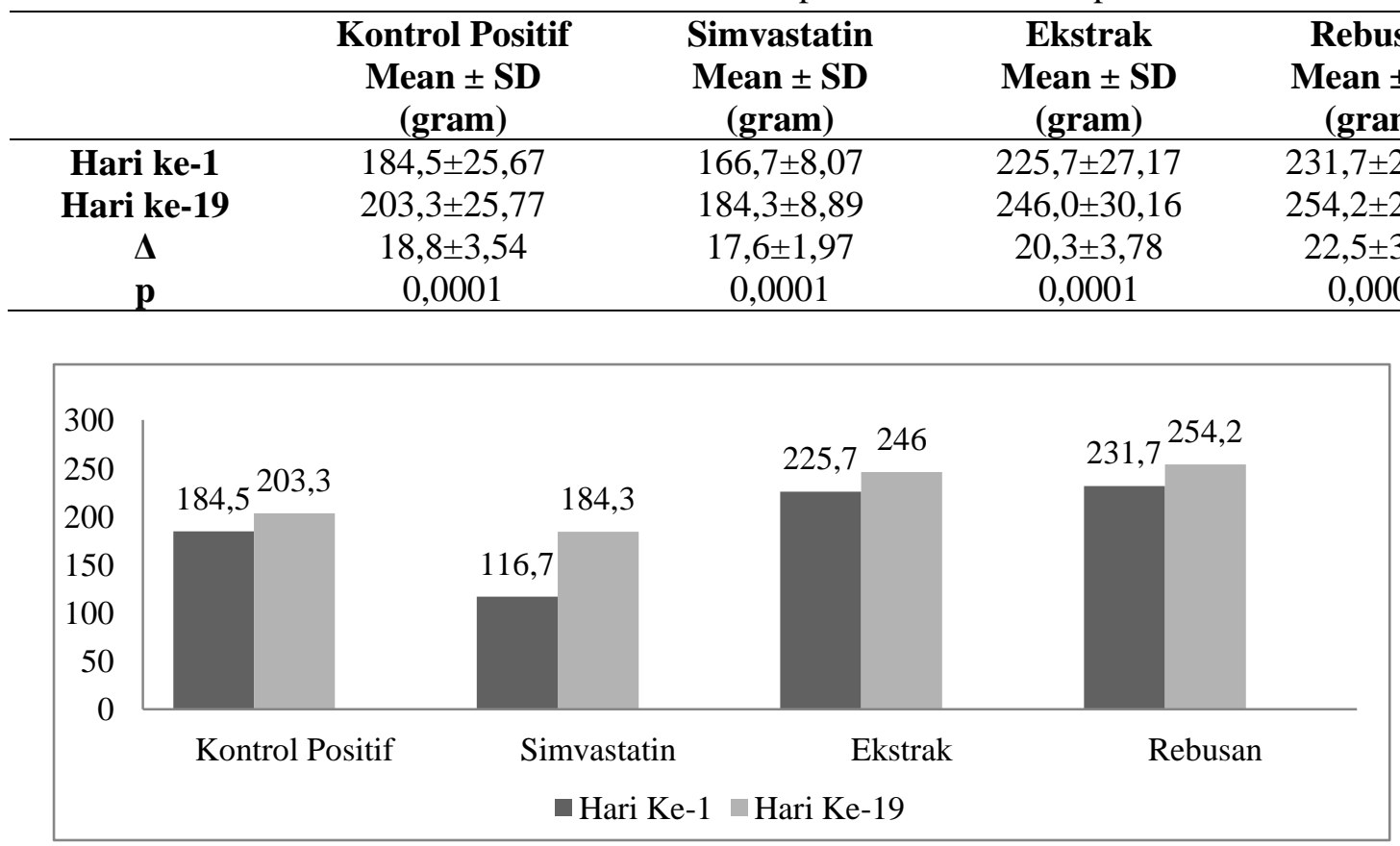

Diagram 1. Perbedaan Berat Badan Tikus pada Hari Ke-1 sampai Hari ke-19

Berdasarkan hasil penelitian, diperoleh pada kelompok rebusan, yaitu 22,5 gram dan hasil bahwa terdapat perbedaan antara berat badan paling rendah terdapat pada kelompok simvastatin hari ke-1sampai hari ke-19 pada semua kelompok. yaitu 17,6 gram.

Selisih berat badan tikus paling tinggi terdapat

Tabel 3. Perbedaan Asupan Pakan Tikus pada Hari Ke-5 sampai Hari Ke-19

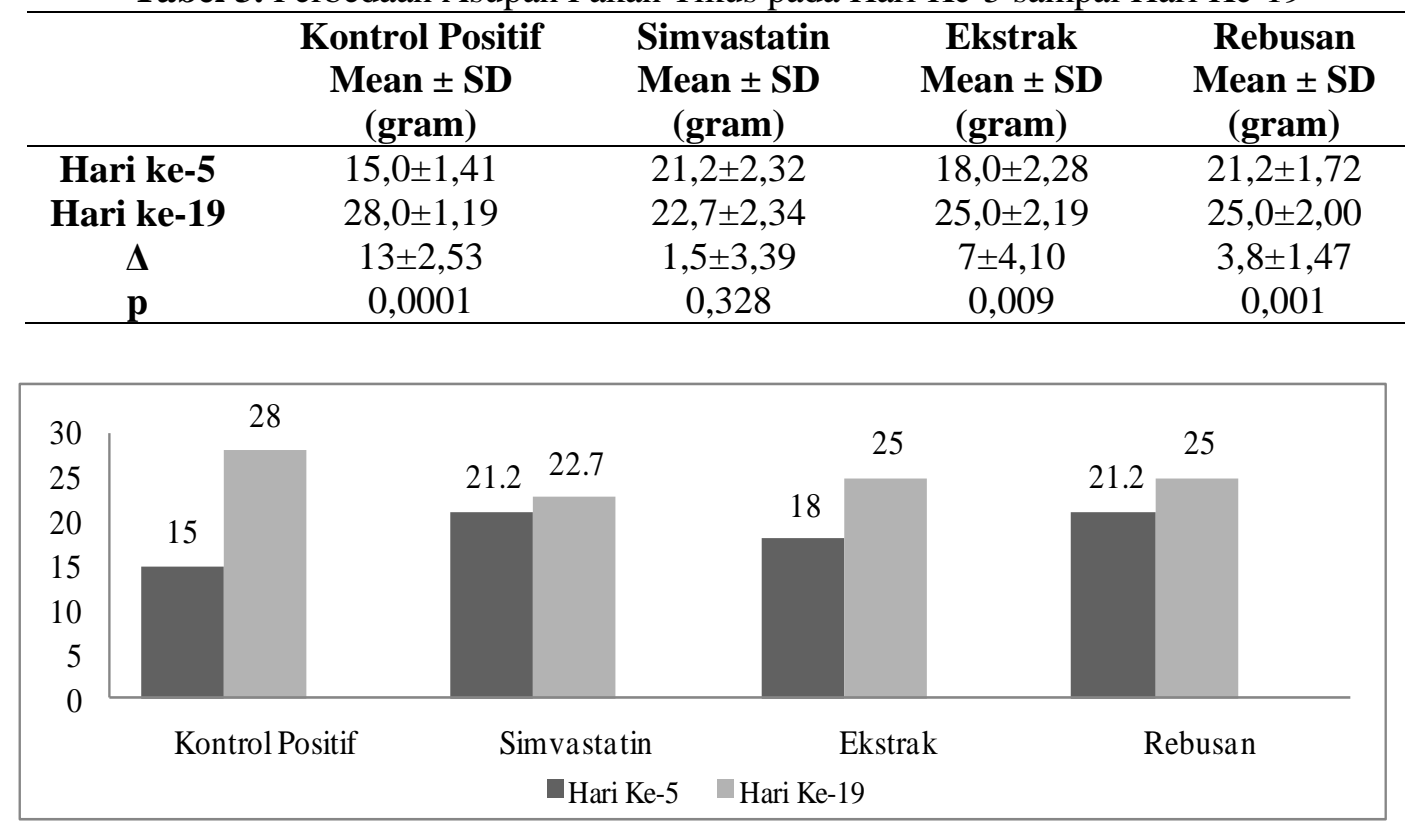

Diagram 2. Perbedaan Asupan Pakan Tikus pada Hari Ke-5 sampai Hari ke-19

Hasil analisis menunjukkan bahwa terdapat perbedaan antara asupan pakan hari ke-5 sampai hari ke-19 pada kelompok kontrol positif, ekstrak, dan rebusan. Selisih asupan pakan tikus paling tinggi terdapat pada kelompok kontrol 
positif, yaitu 13 gram dan paling rendah terdapat pada kelompok simvastatin yaitu 1,5 gram.

\section{Analisis Kadar Kolesterol LDL}

Pemeriksaan kadar kolesterol LDL dilakukan pada hari ke-4 sampai hari ke-19.
Berikut gambaran rerata kadar kolesterol LDL yang ditampilkan pada Tabel 4.

Tabel 4. Perbedaan Kadar Kolesterol LDL Tikus pada Hari Ke-4 sampai Hari Ke-19

\begin{tabular}{ccccc}
\hline & $\begin{array}{c}\text { Kontrol Positif } \\
\text { Mean } \pm \text { SD } \\
(\mathbf{m g} / \mathbf{d L})\end{array}$ & $\begin{array}{c}\text { Simvastatin } \\
\text { Mean } \pm \text { SD } \\
(\mathbf{m g} / \mathbf{d L})\end{array}$ & $\begin{array}{c}\text { Ekstrak } \\
\text { Mean } \pm \text { SD } \\
(\mathbf{m g} / \mathbf{d L})\end{array}$ & $\begin{array}{c}\text { Rebusan } \\
\text { Mean } \pm \text { SD } \\
(\mathbf{m g} / \mathbf{d L})\end{array}$ \\
\hline Hari ke-4 & $17,2 \pm 1,94$ & $14,0 \pm 1,35$ & $14,7 \pm 2,01$ & $16,8 \pm 1,91$ \\
Hari ke-19 & $96,9 \pm 3,61$ & $16,9 \pm 1,75$ & $40,9 \pm 2,79$ & $55,1 \pm 2,29$ \\
$\boldsymbol{\Delta}$ & $79,7 \pm 4,33$ & $2,9 \pm 2,33$ & $26,2 \pm 3,14$ & $38,3 \pm 3,12$ \\
$\mathbf{p}$ & 0,0001 & 0,030 & 0,0001 & 0,0001 \\
\hline
\end{tabular}

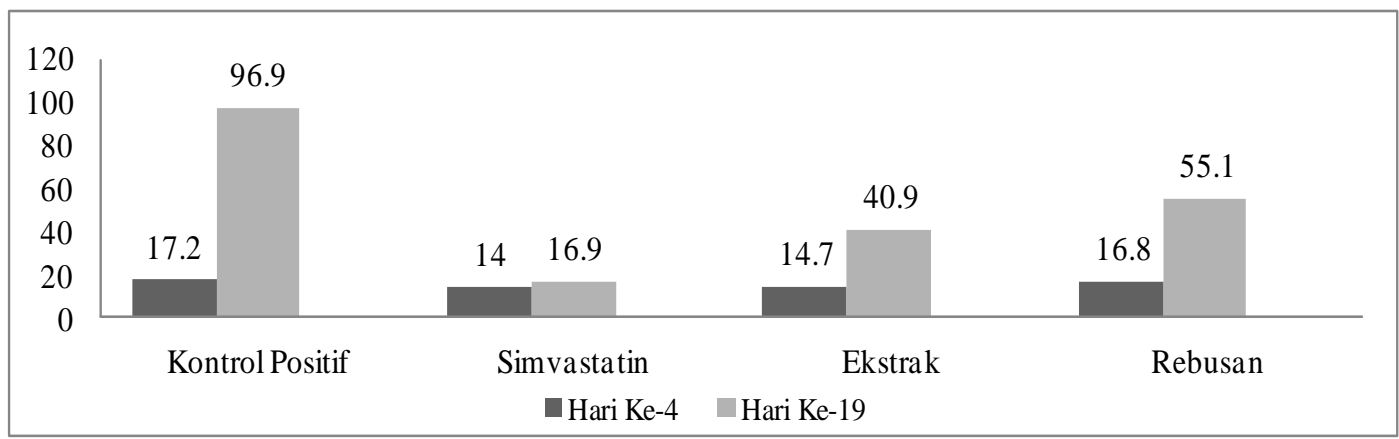

Diagram 3. Perbedaan Kadar Kolesterol LDL Tikus pada Hari Ke-4 sampai Hari Ke-19

Hasil analisis menunjukkan adanya peningkatan kadar kolesterol LDL pada semua kelompok selama 14 hari perlakuan, diketahui bahwa peningkatan paling rendah pada keempat kelompok terdapat pada kelompok simvastatin. Pada kelompok ekstrak mengalami peningkatan kadar kolesterol LDL lebih rendah dibandingkan dengan kelompok rebusan. Uji statistik menunjukkan adanya perbedaan kadar kolesterol LDL pada semua kelompok.
Hasil uji One Way Anova berat badan menunjukkan bahwa tidak terdapat perbedaan perubahan pada semua kelompok. Uji Kruskall Wallis asupan pakan menujukkan terdapat empat perbedaan perubahan asupan pakan dan uji One Way Anova kadar kolesterol LDL menunjukkan bahwa terdapat enam perbedaan perubahan kadar kolesterol LDL.

Tabel 5. Kelompok yang Memiliki Perbedaan Perubahan Asupan Pakan Tikus

\section{${ }^{\mathrm{c} U j i}$ Mann Whitney}

\begin{tabular}{lcc}
\hline & Kelompok & $\mathbf{P}$ \\
\hline 1. & Kontrol Positif vs Simvastatin & $0,004^{\mathrm{c}}$ \\
2. & Kontrol Positif vs Ekstrak & $0,024^{\mathrm{c}}$ \\
3. & Kontrol Positif vs Rebusan & $0,004^{\mathrm{c}}$ \\
4. & Simvastatin vs Ekstrak & $0,027^{\mathrm{c}}$ \\
\hline
\end{tabular}

Berdasarkan uji Mann Whitney, diperoleh hasil bahwa terdapat empat perbedaan perubahan asupan pakan antara kelompok kontrol positif dan

simvastatin $(\mathrm{p}=0,004)$; kontrol positif dan ekstrak $(\mathrm{p}=0,024)$; kontrol positif dan rebusan $(\mathrm{p}=0,004)$; serta simvastatin dan ekstrak $(\mathrm{p}=0,027)$.

Tabel 6. Kelompok yang Memiliki Perbedaan Perubahan Kadar Kolesterol LDL

\begin{tabular}{lcc}
\hline & Kelompok & P \\
\hline 1. & Simvastatin vs Kontrol Positif & $0,0001^{\mathrm{d}}$ \\
2. & Simvastatin vs Ekstrak & $0,0001^{\mathrm{d}}$
\end{tabular}




\begin{tabular}{lcl}
3. & Simvastatin vs Rebusan & $0,0001^{\mathrm{d}}$ \\
4. & Ekstrak vs Kontrol Positif & $0,0001^{\mathrm{d}}$ \\
5. & Ekstrak vs Rebusan & $0,0001^{\mathrm{d}}$ \\
6. & Rebusan vs Kontrol Positif & $0,0001^{\mathrm{d}}$ \\
\hline
\end{tabular}

${ }^{\mathrm{d}} \mathrm{Uji}$ Post Hoc

Hasil uji Post Hoc menunjukkan bahwa terdapat enam perbedaan perubahan kadar kolesterol LDL antara kelompok simvastatin dan kontrol positif; simvastatin dan ekstrak; simvastatin dan rebusan; ekstrak dan kontrol positif; ekstrak dan rebusan; serta rebusan dan kontrol positif.

\section{PEMBAHASAN}

Hasil penelitian menunjukkan adanya peningkatan kadar kolesterol LDL yaitu 79,7 mg/dL pada kelompok kontrol positif; 38,3 mg/dL pada kelompok rebusan; 26,2 $\mathrm{mg} / \mathrm{dL}$ pada kelompok ekstrak; serta 2,9 mg/dL pada kelompok simvastatin. Kelompok kontrol positif mengalami peningkatan kadar kolesterol LDL paling tinggi dibandingkan dengan kelompok lainnya. Peningkatan kadar kolesterol LDL pada kelompok ekstrak $(26,2 \mathrm{mg} / \mathrm{dL})$ lebih rendah dibandingkan dengan kelompok rebusan $(38,3 \mathrm{mg} / \mathrm{dL})$ pada tikus Sprague Dawley yang diberi pakan tinggi lemak. Berat badan sebelum dan selama perlakuan mempengaruhi kadar kolesterol LDL. Peningkatan berat badan tikus paling tinggi terdapat pada kelompok rebusan, yaitu 22,5 gram dan paling rendah terdapat pada kelompok simvastatin, yaitu 17,6 gram. Berat badan yang meningkat selama perlakuan dapat meningkatkan produksi lipoprotein yang mengandung LDL sehingga kadar kolesterol LDL menjadi tinggi. ${ }^{12}$ Peningkatan kadar kolesterol LDL dan berat badan tikus juga dapat dipengaruhi oleh asupan pakan tikus selama perlakuan.

Selisih asupan pakan tikus pada hari ke-5 dan hari ke-19 paling tinggi terdapat pada kelompok kontrol positif, yaitu 13 gram dan paling rendah terdapat pada kelompok simvastatin, yaitu 1,5 gram. Pemberian diet tinggi lemak berpengaruh besar terhadap kadar LDL dalam plasma darah. Makanan yang mengandung lemak jenuh dapat meningkatkan kolesterol darah sebanyak $15-25 \%$. Diet tinggi asam lemak jenuh dan kolesterol menyebabkan kadar kolesterol LDL meningkat, disebabkan karena LDL merupakan lipoprotein pengangkut kolesterol terbesar pada manusia. Penurunan kadar kolesterol LDL melalui diet sehari-hari dapat menurunkan kadar kolesterol melalui perubahan jumlah reseptor kolesterol LDL. ${ }^{11}$ LDL merupakan lipoprotein yang mengandung kolesterol tertinggi dibandingkan dengan lipoprotein lainnya. LDL dalam pembentukannya membutuhkan apolipoprotein primer yaitu apolipoprotein B. Overekspresi dari Apo-B dapat meningkatkan kadar kolesterol LDL pada tikus dan penurunan dari Apo-B dapat menurunkan kadar kolesterol LDL pada tikus. ${ }^{13}$ Pada penelitian ini, ketiga kelompok tikus Sprague Dawley yang diberi perlakuan pemberian simvastatin, ekstrak, dan rebusan daun salam tidak melalui tahap hingga hiperkolesterolemia. Pemberian pakan standar, pakan tinggi lemak, dan perlakuan pemberian simvastatin, ekstrak, serta rebusan daun salam dilakukan secara bersamaan, sehingga tidak dapat terjadi penurunan kadar kolesterol LDL tetapi peningkatan paling rendah terjadi pada kelompok yang diberi simvastatin dan peningkatan kadar kolesterol LDL pada kelompok yang diberi ekstrak daun salam lebih rendah dibandingkan dengan kelompok yang diberi rebusan daun salam.

Pemberian ekstrak dan rebusan daun salam mampu mengurangi peningkatan kadar kolesterol LDL pada tikus Sprague Dawley selama perlakuan. Daun salam (Eugenia polyantha) mengandung bahan-bahan aktif yang dapat menurunkan kadar kolesterol LDL, salah satunya adalah flavonoid. Flavonoid sebagai antioksidan memiliki mekanisme penurunan kolesterol LDL. Quercetin merupakan bagian dari flavonoid dengan sebutan flavonol yang paling banyak terdapat pada makanan. Quercetin dapat menurunkan kadar kolesterol total dan kadar kolesterol LDL dengan cara menghambat sekresi Apo-B 100 pada sel CaCO-2 serta dapat menurunkan aktivitas MTP yang berperan pada pembentukan lipoprotein dengan mengkatalisa perpindahan lipid ke molekul Apo-B. Quercetin juga dapat menghambat aktivitas enzim HMG-KoA reduktase, yaitu enzim yang berperan dalam pembentukan kolesterol. ${ }^{13}$ Sifat quercetin sebagai antioksidan dapat mencegah oksidasi LDL dengan mengikat radikal bebas dan transisi ion logam dalam menghambat peroksidasi lipid. Peroksidasi lipid adalah proses perubahan asam lemak tidak jenuh menjadi radikal bebas melalui abstraksi hidrogen. Peroksidasi lipid dapat menimbulkan kerusakan seperti penyakit jantung. ${ }^{14}$ 
Pada kelompok perlakuan yang diberi ekstrak daun salam mengalami peningkatan kadar kolesterol LDL yang lebih rendah dibandingkan dengan kelompok yang diberi rebusan daun salam. Hal ini dapat disebabkan oleh kandungan flavonoid yang terdapat pada ekstrak daun salam lebih tinggi dibandingkan dengan kadar flavonoid yang terkandung dalam rebusan daun salam. Kadar flavonoid rata-rata yang terkandung pada ekstrak daun salam yaitu 11181,02 ppm sedangkan pada rebusan daun salam sebesar 24,50 ppm. Konsentrasi quercetin dalam flavonoid daun salam dapat dipengaruhi oleh proses persiapan dan penyimpanan. Quercetin mengalami degradasi termal dan tindakan melalui pencucian dan perebusan dalam air mendidih. ${ }^{14}$ Proses pembuatan ekstrak dan rebusan daun salam pada persiapan sebelum perlakuan memiliki perbedaan suhu penyimpanan dan suhu pemanasan. Rebusan daun salam mengalami penurunan kandungan quercetin karena dalam proses pembuatannya dilakukan pada suhu $100{ }^{\circ} \mathrm{C}$ sedangkan ektrak daun salam menggunakan metode maserasi yang menggunakan suhu penyimpanan serta suhu pemanasan yang lebih rendah dibandingkan proses pembuatan rebusan daun salam.

\section{SIMPULAN}

Pemberian rebusan daun salam tidak dapat menurunkan kadar kolesterol LDL pada tikus Sprague Dawley yang diberi pakan tinggi lemak namun peningkatan kadar kolesterol LDL pada kelompok rebusan lebih rendah dibandingkan dengan kelompok kontrol positif serta lebih tinggi peningkatannya dibandingkan dengan kelompok ekstrak dan simvastatin.

\section{DAFTAR PUSTAKA}

1. Yusnidar. Faktor-faktor risiko penyakit jantung koroner pada wanita usia > 45 tahun (studi kasus di RSUP Dr. Kariadi Semarang) [tesis]. Semarang: Universitas Diponegoro; 2007.

2. World Health Organization. Noncommunicable disease country profiles 2011.[serial online]. [dikutip pada tanggal 10 Juni 2013]. Diunduh dari http://who.int/nmh/countries/idn_en.pdf.

3. Sudijianto K. Dislipidemua di Kota Padang, dll; 2004.

4. Gandha N. Hubungan Perilaku dengan Prevalensi Dislipidemia pada Masyarakat Kota Ternate tahun 2008. Universitas Indonesia; 2009.

5. Baraas F. Kardiologi Molekuler. Jakarta: Kardua Iqratama; 2004. Hal. 250-51.
6. Nestel PJ. Management of Dyslipidemua: Ecidence and Practical Recommendation. Australian Family Physician Vol. 37. No. 7. July 2008.

7. WHO. Cardiovascular diseases [Online]. 2013. [cited 2013 March 19]; Available from: URL: http://www.who.int/cardiovascular_diseases/en/.

8. Krummel DA. Medical Nutrition Therapy in Cardiovascular Disease. In: Janice LR, Sarah G. Couch. Krause's food, Nutrition, and Diet Therapy $13^{\text {th }}$ edition. Philadelphia: WB Saunders Company; 2012.p.742-58.

9. Dewoto, Hedi R. Pengembangan obat tradisional Indonesia menjadi fitofarmaka. Departemen Farmakologi, Fakultas Kedokteran Universitas Indonesia, Jakarta. Maj Kedokt Indon, Volum: 57, Nomor: 7, Juli 2007.

10. Moeloek FA. Herbal and traditional medicine: National perspectives and policies in Indonesia. Jurnal Bahan Alam Indonesia 2006;5(1):293-97.

11. Pidrayanti, Luh Tut M. U. Pengaruh pemberian ekstrak daun salam (Eugenia polyantha) terhadap kadar LDL kolesterol serum tikus jantan galur wistar hiperlipidemia [karya tulis ilmiah]. Semarang: Universitas Diponegoro; 2008.

12. Olivera T, Ricardo KFS, Almeida MR, Costa MR, Nagem TJ. Hypolipidemic Effect of Flavonoids and Cholestyramine in Rats Tania. Latin American Journal of Pharmacy 2007; 26 (3): 407-10.

13. Casaschi Adele, Wang Qi, Dang Ka'ohimanu, Richards Alison, Theriault Andre . Intestinal apolipoprotein B secretion is inhibited by the flavonoid quercetin: potential role of microsomal triglycerida transfer protein and diacylglycerol acyltransferase. PubMed. Lipids. 2002 Jul;37(7):647-52.

14. Bentz, Alexandra B., A Review of Quercetin: Chemistry, Antioxidant Properties, and Bioavailability. Journal of Young Investigators. April 2009; 120-28. 